\title{
Cost-Return Analysis of Fodder Production in Selected Areas of Bangladesh
}

\author{
S. Islam ${ }^{1 *}$, J. Begum ${ }^{1}$, N.R. Sarker ${ }^{2}$ and M. Khatun ${ }^{1}$ \\ ${ }^{1}$ Socioeconomic Research Division; ${ }^{2}$ Animal Production Research Division, Bangladesh Livestock \\ Research Institute, Savar, Dhaka-1341, Bangladesh
}

\begin{abstract}
The study was conducted to determine fodder production, estimated profitability of fodder farmers and constrains to its production. In this regard, four study areas were selected from four districts viz: Dinajpur, Jessore, Kurigram and Rangpur purposively considering the concentration of fodder production. A purposive sampling technique was followed for collecting primary data from the field. Two categories of sample farmers were selected namely: i) Fodder Producer cum seller (FPS); ii) Fodder Producer cum Dairy owner (FPDO) having 1-2 dairy cows as small, 3-4 dairy cows as medium and 5 and above dairy cows as large farmer.A total of 160 fodder farmers were interviewed. Field survey method and focus group discussions were followed to collect necessary data and information. Descriptive statistics were applied to meet the objectives and to get the desirable outputs. The study revealed that 99 per cent FPS cultivated napier (Pennisetumpur-pureum), whereas, fodder producer cultivated 90 per cent. The ratio of land under fodder production and farm size was 0.10 and 0.29 acre for producer and FPS, respectively. In case of cattle holdings, fodder farmers reared more cross-bred cattle compared to local cattle. The highest number cross-bred cattle $(22.95 / \mathrm{farm})$ were reared by producer in Dinajpur district,whereas FPS reared 9.88 cattle per farm in Jessore district.The production cost of fodder for producer was estimated the highest (Tk 1,87,598/ha) in Kurigram district and the lowest (Tk 1,71,883/ha) for FPS was also in Kurigram district. The bio-mass yield was the highest (214.05 tha) for producer in Dinajpur district and the lowest was (201.45 t/ha) for FPS in Kurigram district. Annual net return from fodder production was estimated the highest (Tk 2,12,272/ha) for FPS in Jessore district and the lowest (Tk 1,29,806/ha) for FPS in Kurigram district. The BCR was the highest 2.18 for FPS in Jessore district and the lowest was 1.75 for FPS in Kurigram district. Problems faced by the fodder farmers were lack of HYV fodder species, lack of knowledge, and lack of input facilities. The study suggested supply of HYV fodder, provide training on fodder cultivation and preservation, availability of more milk producing cattle breed in fodder production areas.
\end{abstract}

(Key words: Fodder, production, income, cost, return)

\section{Introduction}

Bangladesh is basically an agricultural country and nearly three-fourth population depends on agriculturefor livelihood. Major parts of population live in rural areas. Livestock sub-sector plays an important role in developing the rural economy of the country providing balanced and cheap nutritional food in the form of milk and other

*Corresponding Author : s.islam_blri@yahoo.com

Bang. J. Livs. Res. Vol. 20 (1 \& 2), 2013; P. 54-67 ISSN 1022-3851 
animal products.Livestock is also an important asset for the farm families. Therefore, rapid growth of livestock sector is most desirable not only to retain steady agricultural growth but also to reduce rural poverty. The share of agriculture sector in national GDP is 18.70 percent and the share of livestock sub-sector is 2.45 percent and it provides employment for about 25 per cent of the total labour force (BER, 2013). Livestock also creates opportunities to exploit common grazing lands, supports collateral and savings, and diversify income (Faruque, 2003). One of the main reasons for the low productivity of our livestock is malnutrition, under-nutrition or both, beside the low genetic potential of the animals. Adequate supply of quality fodder is a vital factor for supporting increased productivity of farm animals. The country is highly deficient in. respect of availability of green fodder, dry fodder and concentrates. Fodder deficient can mainly be attributed to our limitations in increasing the area under fodder crops, limited availability of high yielding variety fodder, lack of quality seeds of improved varieties, poor quality of dry fodder, changing cropping pattern in favour of cash crops etc. Besides, low priority efforts to invest in fodder production, lack of post-harvest management for surplus fodder, poor management of pasture lands and inadequate research, extension and manpower support also augmented the deficit situation of fodders.

The steady availability of fodder is a pre-requisite to make livestock production cost efficientespecially of milk. Feed and fodder cost constitute about $60-70 \%$ of cost of milk production (Grover and Kumar, 20I2). Without ensuring an adequate supply of quality fodder, the achievement of desired growth of livestock sub-sector in the coming years looks almost impossible. The study conducted by Sayeed et al., (2008) showed that the average acreage under fodder cultivation was increasing; it is a matter of good hope for our livestock sub-sector. Fodder contains a major protein of daily ration of milch animals and therefore, cultivation of nutritious and high yielding variety fodder is inevitable. The authors also revealed that the highest amount of income was observed from harvested fodder based cropping pattem. Profitable livestock farming depends mainly on adequate availability of fodder with reasonable price. In Bangladesh, fodder production and its preservation practice is a very new chapter. Despite various impediments, the farmers are very much eager to produce fodder for their livestock as nutritious feed. But research work is very much scanty in this arena.

The production of high quality fodders is fundamental for rearing improved breeds of cattle. As the number of animal population are increasing over the years, the threat of providing adequate feed and fodder become so acute. Fodder provides to animals not to require nutrient but fills the rumen to satisfy the animas.In financial year 2011-12, the total livestock population were 528.36 lac, whereas large animal were 246.38 lac (BBS, 2012). 
At present, fodder demand is becoming a challenging issue in most of the developing countries including Bangladesh. The quality feed and fodder supply is vital importance in sustaining the growth of the livestock sub-sector in future.Efforts are being made and under way for reducing the gap between the requirement and availability of fodders through technological interventions to increase the yields, bringing more area under fodder crops, conservation and improving the nutritive value of the poor quality fodder. The present study, therefore, was undertaken to estimate profitability of fodder. It is expected that further study on the aspects would add new dimension to the government policy. The specific objectives of the study were as follows:

i. Estimation of the costs and returns associated with the cultivation of fodder crops;

ii. Study on the fodder production in different locations; and

iii. Explore constrains to the production of fodder.

\section{Materials and Methods}

Study areas were selected from four upazilas of four districts viz:Badarganjunder Rangpur district, Chirirbandar under Dinajpur district, Kurigram Sadar under Kurigram district and Jessore Sadar under Jessore district. Both primary and secondary data were used in this study. A purposive sampling technique was followed for collection of primary data from the field. A total of 160 fodder farmers were divided into two categories namely: i) Fodder producer cum seller (FPS) $(n=80)$ and ii) Fodder producer cum dairy owner (FPDO) $(n=80)$. All farmers were interviewed for the collection of necessary data and information (Table 1).

Fodder cultivation is largely related with the farmers' socioeconomic conditions. Socioeconomic factors were also studied. The primary data were collected by direct interview method with the selected respondents by a structured interview schedule. The interview schedule was pre-designed and pre-tested. After pre-testing, necessary corrections, modifications and adjustments were made and thus, final questionnaire was prepared for data collection. The survey was confined during December' 2013 to March' 2014. All the data, thus, collected were coded, tabulated, summarized and processed using computer SPSS Program. Moreover, four focus group discussions (FGD) were organized to examine the fodder production in the study areas. The analysis was done using descriptive statistics like percentage, frequency distribution, mean, and ranking. Profit was derived in terms of gross return, gross margin, net return and benefit cost ratio. The formula used for the calculation of financial profitability is discussed below:

$$
\Pi=\sum_{i=1}^{n}\left(P_{Y_{i}}, Y_{i}\right)-\sum_{i=1}^{n}\left(P_{X_{i}}, X_{i}\right)-T F C
$$

Where, $\Pi=$ Profit; $P_{Y i}=$ Price per unit of the i-th produce; $Y_{i}=$ Quantity of the i-th produce; $P_{X i}=$ Price per unit of the i-th inputs; $X_{i}=$ Quantity of the i-th inputs; TFC $=$ Total fixed costs; and $i=1,2,3, \ldots, n$ (number of items). 
Table 1. Distribution of sample farmers in the study areas

\begin{tabular}{|c|c|c|c|c|c|}
\hline \multirow{2}{*}{ Sample categories } & \multicolumn{4}{|c|}{ Study Areas } & \multirow[t]{2}{*}{ Sample size } \\
\hline & Rangpur & Dinajpur & Kurigram & Jessore & \\
\hline Fodder producer cum seller & 20 & 20 & 20 & 20 & 80 \\
\hline Fodder producer cum Dairy owner & 20 & 20 & 20 & 20 & 80 \\
\hline Total & 40 & 40 & 40 & 40 & 160 \\
\hline
\end{tabular}

Gross return was calculated by multiplying the total volume of output of an enterprise by the average price in the harvesting period (Dillonand Hardaker, 1993). The following equation was used to estimate gross return:

$$
\mathrm{GR}_{\mathrm{i}}=\sum_{i=1}^{n} Q_{i} P_{i}
$$

Where,

GRi = Gross return from ith product $(\mathrm{Tk} /$ Year $) ; \mathrm{Qi}=$ Quantity of the ith product (Kg./Year); $\mathrm{P}=$. Average price of the ith product $(\mathrm{Tk} /$ Year); and $\mathrm{i}=1,2,3 \ldots \ldots \ldots \ldots . . \mathrm{n}$.

The benefit cost ratio ( $B C R$ ) is a relative measure which is used to compare benefit per unit of cost. BCR was estimated as a ratio of gross benefit and gross costs. The formula of calculating BCR (undiscounted) is shown as below:

Benefit cost ratio $=\frac{\text { Gross benefit }}{\text { Gross cost }}$

Farmer's category: Marginal (0.02-0.19 ha), Small $(0.20 \times 1.01 \mathrm{ha})$, Medium (1.02-3.03) and Large (>3.04 ha) as per BBS (2012).

\section{Results and Discussion}

\section{Socioeconomic profile of fodder farmer}

Socioeconomic parameters such as age, education, occupation, experiences, farm size, family size and dependency ratio were studied to know the farmers socioeconomic conditions. Therefore, an attempt has been made here to investigate some important as well as relevant socioeconomic characteristics of the respondent farmers were classified into four age groups as presented in Table 2. The classified age groups were up to 30 years, $31-45$ years, 46 to 60 years and above 60 years. The highest percent of farmers were in age group 31-45 years for producer and 46-60 years for producer cum seller indicating that they were in productive stage and to give more labour to their farm activities.Education helps men to have day-to-day information on the modern technology and techniques together with technological changes in various production processes. It is evident that the highest 38 per cent and 34 per cent of farmers were in SSC level for producer and FPS, respectively.On an average, 60 per cent producer and 67.50 per cent FPS were engaged fully on agriculture as primary occupation. The second highest occupations were found 31.25 per cent and 16.25 per cent as business for producer and FPS, respectively as primary occupation. On the other hand, it is found that 37.50 per cent producer and 31.25 per cent FPS had taken agriculture as secondary occupation. The study found that 50 per cent producer and 


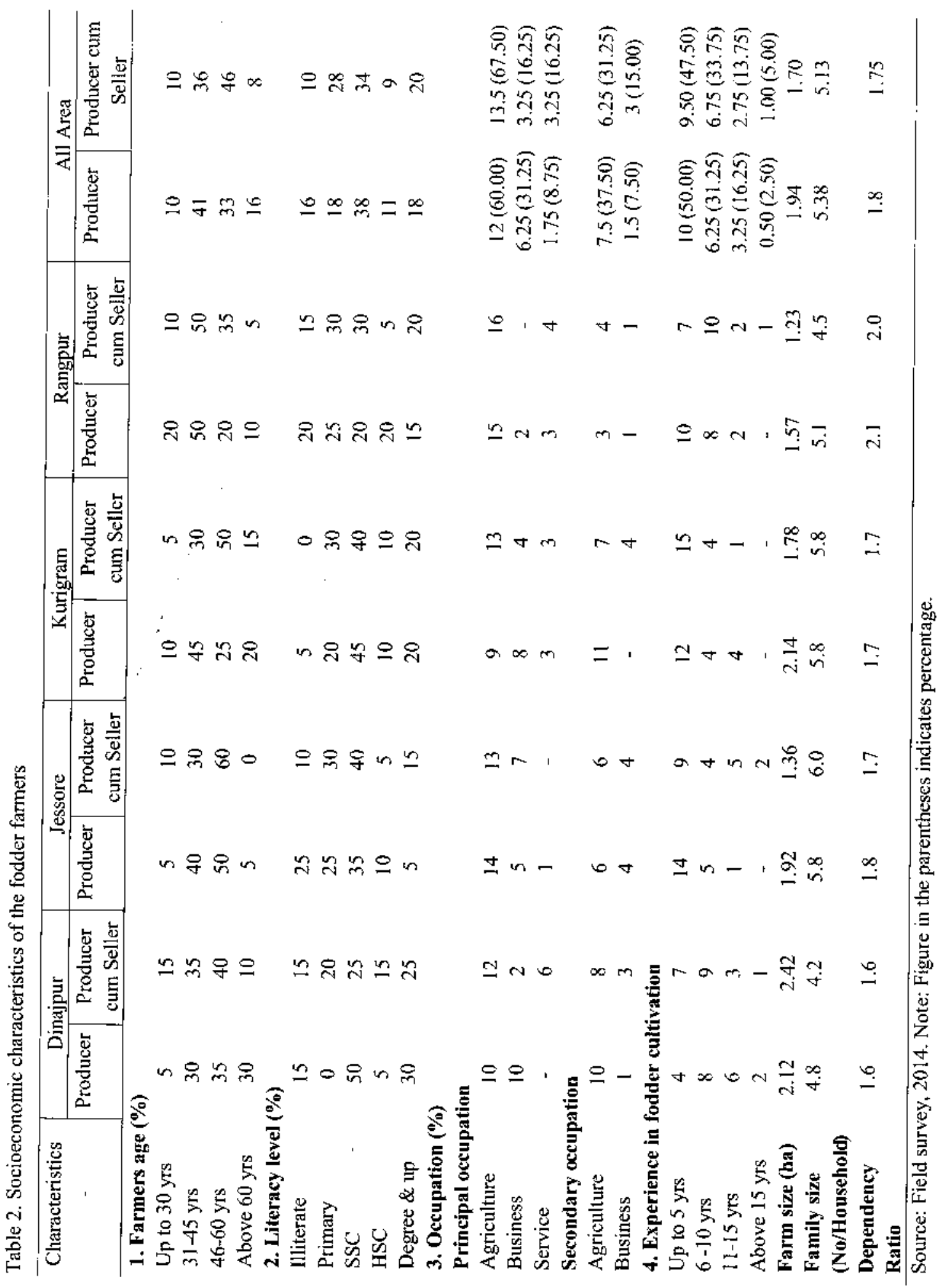


47.50 per cent FPS had up to 5 years of experience of producing fodder for their livestock. It also revealed that average farm size for producer was 1.94 hectare and for FPS was 1.70 hectare.The average family size in the study area was 5.38 persons per family for producer and 5.13 persons per family for FPS. Dependency ratio was 1.8 and 1.75 for producer and FPS, respectively (Table 2).

\section{Farmer's category}

From Table 3, on an average, 42 per cent producer fallen into small farm category who produced fodder for their livestock. On the other hand, 44 per cent FPS fallen into small farm category who produce fodder for their livestock and sold their surplus production. Small and medium farmers cultivated fodder more than the marginal and large farmers.

\section{Ratio of land under fodder production and farm size}

On an average, producer used 0.18 ha land for fodder production of the farm. The producer of Dinajpur district used 0.34 ha land for fodder production as highest followed by Rangpur district ( $0.16 \mathrm{ha}$ ). On the other hand, FPS used 0.33 ha land for fodder production. The reason may be the FPS sold surplus production and gained satisfactory income. The FPS of Jessore district used 0.48 ha land for fodder production followed by Rangpur district ( $0.41 \mathrm{ha})$. Land under fodder production and farm size ratio was found 0.07 and 0.23 for producer and FPS, respectively (Table 4).

Table 3. Farmers' category according to land holdings

\begin{tabular}{|c|c|c|c|c|}
\hline Category of Farmer & Marginal & Small & Medium & Large \\
\hline \multicolumn{5}{|l|}{ A. Dinajpur } \\
\hline Producer & - & 3 & 5 & 12 \\
\hline Producer cum seller & 1 & 8 & 6 & 5 \\
\hline \multicolumn{5}{|l|}{ B. Jessore } \\
\hline Producer & 1 & 13 & 3 & 3 \\
\hline Producer cum seller & - & 10 & 7 & 3 \\
\hline \multicolumn{5}{|l|}{ C. Kurigram } \\
\hline Producer & - & 6 & 9 & 5 \\
\hline Producer cum seller & - & 7 & 10 & 3 \\
\hline \multicolumn{5}{|l|}{ D. Rangpur } \\
\hline Producer & - & 12 & 4 & 4 \\
\hline Producer cum seller & - & 10 & 10 & - \\
\hline \multicolumn{5}{|l|}{ E. All areas } \\
\hline Producer & $0.25(1.25)$ & $8.50(42.50)$ & $5.25(26.25)$ & $6.00(30.00)$ \\
\hline Producer cum seller & $0.25(1.25)$ & $8.75(43.75)$ & $8.25(41.25)$ & $2.75(13.75)$ \\
\hline
\end{tabular}

Source: Field survey, 2014. 
Number of cattle reared by the respondent fodder farm in the study area

From the study, it is found that each fodder producer had 3.5 head of local cattle whereas FPS had 2.39 head. The highest (4.55) number of local cattle were in Rangpur district followed by Dinajpur district (3.5 no.) for fodder producer farm. It is also found that producer had 11.25 head of cross-bred cattle whereas FPS had 5.45 head. The highest (22.95) number of cross-bred cattle were in Dinajpur district for producer whereas FPS in Jessore district that was 9.88 in number (Table 5).

Table 4. Ratio of land under fodder production and farm size (Hectare)

\begin{tabular}{lccc}
\hline \multicolumn{1}{c}{ Category of Farmer } & Farm size & Fodder land & Ratio \\
\hline $\begin{array}{l}\text { A. Dinajpur } \\
\quad \text { Producer }\end{array}$ & 4.25 & & \\
$\quad$ Producer cum seller & 1.92 & 0.34 & 0.08 \\
B. Jessore & & 0.25 & 0.13 \\
$\quad$ Producer & 1.8 & 0.09 & 0.05 \\
$\quad$ Producer cum seller & 1.5 & 0.48 & 0.32 \\
C. Kurigram & & & \\
$\quad$ Producer & 3.25 & 0.13 & 0.04 \\
$\quad$ Producer cum seller & 1.45 & 0.16 & 0.11 \\
D. Rangpur & & & \\
$\quad$ Producer & 1.33 & 0.16 & 0.12 \\
$\quad$ Producer cum seller & 1.27 & 0.41 & 0.37 \\
E. All areas & & & \\
$\quad$ Producer & 2.57 & 0.18 & 0.07 \\
$\quad$ Producer cum seller & 1.43 & 0.33 & 0.23 \\
\hline
\end{tabular}
Source: Field survey, 2014

Table 5.Number of cattle reared by the respondent fodder farms (No. Per farm)

\begin{tabular}{lccc}
\hline Category of Farmer & Local & Cross-bred & Both \\
\hline A. Dinajpur & & & \\
$\quad$ Producer & 3.5 & 22.95 & 23.75 \\
$\quad$ Producer cum seller & 1.0 & 4.45 & 4.55 \\
B. Jessore & & & \\
$\quad$ Producer & 2.6 & 7.24 & 6.8 \\
$\quad$ Producer cum seller & 3.0 & 9.88 & 8.9 \\
C. Kurigram & & & \\
$\quad$ Producer & 3.33 & 9.30 & 11.5 \\
$\quad$ Producer cum seller & 3.13 & 4.82 & 5.4 \\
D. Rangpur & & & \\
$\quad$ Producer & 4.55 & 5.5 & 6.1 \\
$\quad$ Producer cum seller & 2.43 & 2.6 & 3.16 \\
E. Ali areas & & & 12.04 \\
$\quad$ Producer & 3.5 & 11.25 & 5.5 \\
\hline Producer cum seller & 2.39 & 5.45 & \\
\hline
\end{tabular}


Types of fodder cultivated by the respondent farmer in the study areas

In different locations of the country, farmers produced different kinds of fodder such as Napier, German, Andropogon, Splendida, Sorghum, Para, Maize. Cowpea, Moringa, Black gram and Triticale. Two to three decade past, the country had huge amount of pasture land. But, it is decreasing day by day and turned into crop field. From the present study, it was found that 90 per cent producer cultivate Napier fodder whereas FPS 99 per cent. The study also found 7.5 per cent producer cultivate German whereas FPS only 1.25 per cent (Table 6 ). A few farmers in Jessore and Kurigram districts produced Garman fodder due to have low land area where otber crops do not grow properly. For computational convenience and very poor number, both type fodder production is excluded. .

\section{Input Use Pattern}

Human labour is the most important component for crop production. Till now, machine power could not replace human labour fully for cultivation. Human labour was mainly employed in land preparation, planting, fertilizer application, weeding and harvesting. The study found that 104 man-days and 99 man-days per hectare per year of hired labour were required for producer and FPS, respectively. On an average, 103056 and 105034 number of fodder cuttings was required for per hectare of land plantation. Producer used cow dung $4635 \mathrm{~kg}$ per hectare of land. On the other hand, FPS used cow dung $5548 \mathrm{~kg}$ per hectare per year. The FPS used more cow dung because of its availability. It is also revealed that per hectare application of Urea by the producer is more than the FPS. The reason may be less use of cow dung (Table 7 ).

Table 6. Types of fodder cultivated by the respondent farmer

\begin{tabular}{|c|c|c|c|}
\hline \multirow{2}{*}{ Category of Farmer } & \multicolumn{2}{|c|}{ Fodder species } & \multirow[b]{2}{*}{ Both } \\
\hline & Napier & German & \\
\hline \multicolumn{4}{|l|}{ A. Dinajpur } \\
\hline Producer & 20 & - & - \\
\hline Producer cum seller & 19 & 1 & - \\
\hline \multicolumn{4}{|l|}{ B. Jessore } \\
\hline Producer & 16 & 3 & 1 \\
\hline Producer cum seller & 20 & - & - \\
\hline \multicolumn{4}{|l|}{ C. Kurigram } \\
\hline Producer & 16 & 3 & 1 \\
\hline Producer cum seller & 20 & - & - \\
\hline \multicolumn{4}{|l|}{ D. Rangpur } \\
\hline Producer & 20 & - & - \\
\hline Producer cum seller & 20 & - & - \\
\hline \multicolumn{4}{|l|}{ E. All areas } \\
\hline Producer & $18(90)$ & $1.5(7.5)$ & 0.5 \\
\hline Producer cum seller & $19.75(99)$ & $0.25(1.25)$ & 0.00 \\
\hline
\end{tabular}

Source: Field survey, 2014. Note: Figure in the parentheses indicate percentage 
Table 7. Level of per hectare input use pattern for producing fodder in the study areas (Per hectare)

\begin{tabular}{|c|c|c|c|c|c|c|c|c|c|c|}
\hline \multirow[t]{2}{*}{ Items } & \multirow{2}{*}{\multicolumn{2}{|c|}{$\begin{array}{c}\text { Dinajpur } \\
\text { Producer Producer } \\
\text { cum seller }\end{array}$}} & \multicolumn{2}{|c|}{ Jessore } & \multicolumn{2}{|c|}{ Kurigram } & \multicolumn{2}{|c|}{ Rangpur } & \multicolumn{2}{|c|}{ All area } \\
\hline & & & Producer & $\begin{array}{l}\text { Producer } \\
\text { cum seller }\end{array}$ & Producer & $\begin{array}{l}\text { Producer } \\
\text { cum scller }\end{array}$ & Producer & $\begin{array}{l}\text { Producer } \\
\text { cum seller }\end{array}$ & Producer & $\begin{array}{l}\text { Producer } \\
\text { cum seller }\end{array}$ \\
\hline \multicolumn{11}{|c|}{ Human labour (man-day/ha) } \\
\hline Family & 66.42 & 64.52 & 49.25 & 45.58 & 69.04 & 50.17 & 58.95 & 67.64 & 61 & 57 \\
\hline Hired labour & 108.92 & 118.23 & 116.79 & 112.71 & 107.88 & 85.53 & 81.85 & 80.68 & 104 & 99 \\
\hline Cutting (no/ha) & 91754 & 97030 & 116524 & 112917 & 95592 & 94364 & 108354 & +115826 & 103056 & 105034 \\
\hline \multicolumn{11}{|c|}{ Organic Manure (kg/ha) } \\
\hline Cow dung & 4298 & 3932 & 5778 & 7342 & 3608 & 4372 & 4858 & 6546 & 4635 & 5548 \\
\hline \multicolumn{11}{|c|}{ Chemical Fertilize (kg/ha) } \\
\hline Urea & 705 & 851 & 695 & 639 & 823 & 660 & 765 & 788 & 747 & 734 \\
\hline TSP & 188 & 154 & 131 & 118 & 145 & 133 & 113 & 115 & 144 & 130 \\
\hline MP & 180 & 169 & 137 & 133 & 142 & 185 & 154 & 170 & 153 & 164 \\
\hline
\end{tabular}

Source: Field Survey, 2014

\section{Cost of Fodder Production}

Costs are the expenses for organizing and carrying out the production process. The cost of production included different variable cost items like land preparation, human labour, fodder cuttings, manure, fertilizer, irrigation etc. Both cash expenditure and imputed value of family supplied inputs were included. Human labour was the major cost items incurred in both producer and FPS. On an average, producer born per hectare human labour cost was Tk. 25963 whereas FPS Tk. 24821. Producer incurred slightly more hired labour cost than FPS. Total variable cost was found Tk. 108010/ha and Tk. $105627 /$ ha by producer and FPS, respectively. Total cost was found Tk. 182415/ha and Tk. 179748/ha by producer and FPS, respectively (Table 8 ).

\section{Profitability of Fodder Production}

On an average, bio-mass yield was found 207.83 tha and $206.73 \mathrm{t} / \mathrm{ha}$ for producer and FPS, respectively. It was found that bio-mass yield was higher $(214.05 \mathrm{t} / \mathrm{ha})$ in Dinajpur district for producer and for FPS in Jessore district (211.77 t/ha). The reason may be good intercultural practices. The average gross return from fodder production was found Tk. 350238/ha and Tk. 361238/ha for producer and FPS, respectively. Gross margin was found Tk. 242228/ha and Tk. $255610 /$ ha for producer and FPS, respectively. Table 4.4 also revealed that net return for producer Tk. 167823/ha and $\mathrm{Tk}$. $181489 /$ ha for FPS. The benefit cost ratio was estimated at 1.92 for producer and 2.01 for FPS on full cost basis (Table 9). 


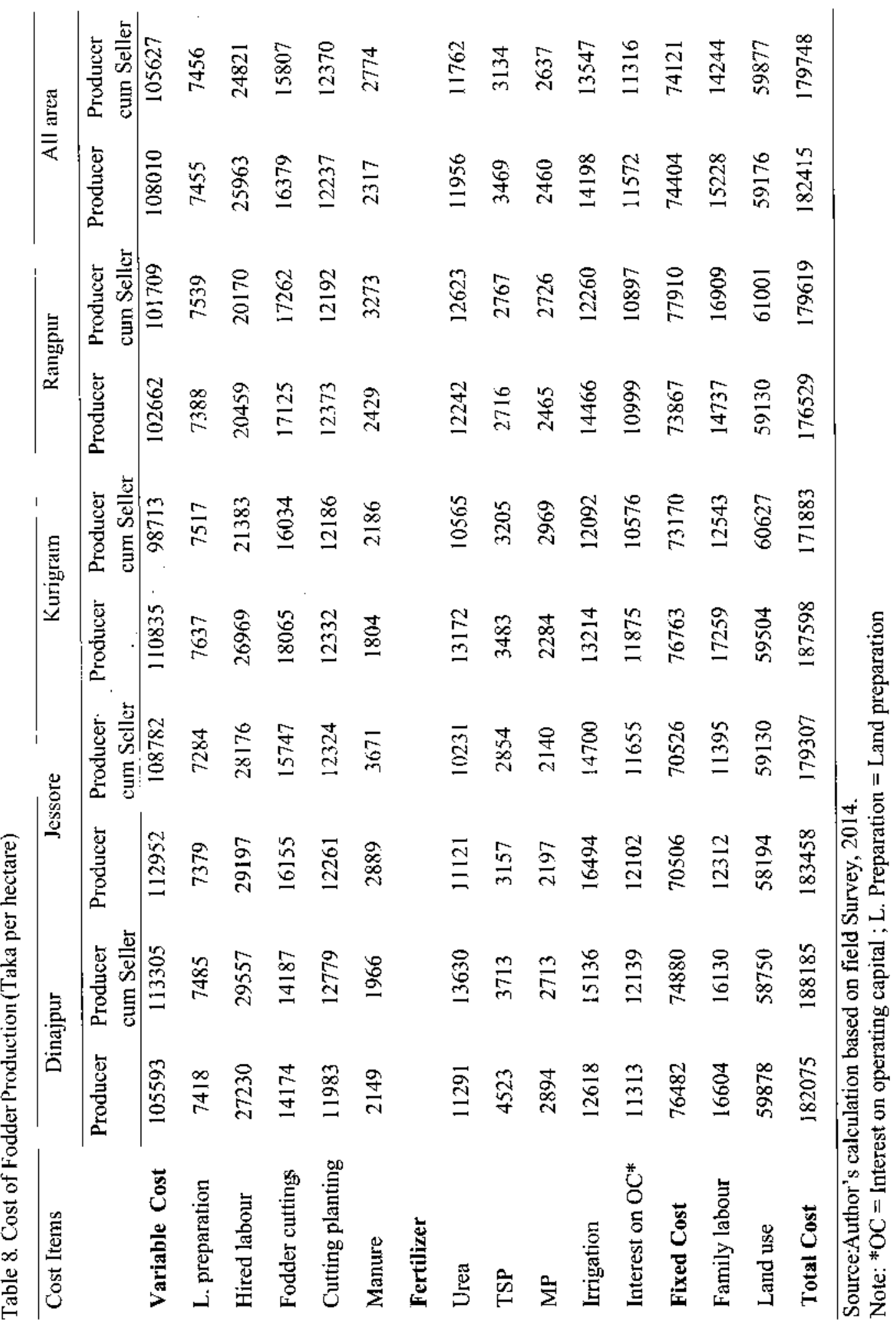


Table 9. Profitability of fodder production (Taka per hectare)

\begin{tabular}{|c|c|c|c|c|c|c|c|c|c|c|}
\hline \multirow{2}{*}{$\frac{\text { Items }}{\text { Farmer's category }}$} & \multicolumn{2}{|c|}{ Dinajpur } & \multicolumn{2}{|c|}{ Jessore } & \multicolumn{2}{|c|}{ Kurigram } & \multicolumn{2}{|c|}{ Rangpur } & \multicolumn{2}{|c|}{ All area } \\
\hline & Producer & $\begin{array}{l}\text { Producer } \\
\text { cum Seller }\end{array}$ & Producer & $\begin{array}{l}\text { Producer } \\
\text { cum Seller }\end{array}$ & Producer & $\begin{array}{l}\text { Producer } \\
\text { cum Seller }\end{array}$ & Produce & $\begin{array}{l}\text { Producer } \\
\text { um Seller }\end{array}$ & Producer & $\begin{array}{l}\text { Producer } \\
\text { cum Seller }\end{array}$ \\
\hline Biomass yield (tha) & 214.05 & 205.36 & 212.46 & 211.77 & 202.39 & 201.45 & 202.40 & 208.35 & 207.83 & 206.73 \\
\hline Price (Tk/ton) & 1835 & 1885 & 1592 & 1849 & 1671 & 1497 & 1637 & 1749 & 1683 & 1745 \\
\hline Gross return (Tk) & 392946 & 387118 & 338281 & 391579 & 338333 & 301689 & $33 \lcm{395}$ & 364566 & 350238 & 361238 \\
\hline Total variable cost & 105593 & 113305 & 112952 & 108782 & 110835 & 98713 & 102662 & 101709 & 108010 & 105627 \\
\hline Total cost & 182075 & 188185 & 183458 & 179307 & 187598 & 171883 & 176529 & 179619 & 182415 & 137423 \\
\hline Gross margin & 287353 & 273813 & 225329 & 282797 & 227498 & 202976 & 228733 & 262857 & 242228 & 255610 \\
\hline Net return & 210871 & 198933 & 154823 & 212272 & 150735 & 129806 & 154866 & 184947 & 167823 & 181489 \\
\hline \multicolumn{11}{|l|}{$\mathrm{BCR}$} \\
\hline Variable cost basis & 3.72 & 3.41 & 2.99 & 3.59 & 3.05 & 3,05 & 3.23 & 3.58 & 3.25 & 3.41 \\
\hline Full cost basis & 2.15 & 2.06 & 1.84 & 2.18 & 1.80 & 1.75 & 1.88 & 2.03 & 1.92 & 2.01 \\
\hline
\end{tabular}

Source: Author's calculation based on field Survey, 2014.

It is also found that the BCRs were different in the selected study areas. In Dinajpur district, the BCR was higher followed by Jessore, Rangpur and Kurigram. In Kurigram district, the fodder marketing system was very poor than all other districts. The study revealed that the BCRs for FPS were higher than the producers in all districts. It indicates that fodder production and selling provides more profit.

\section{Problems Faced by Fodder Farmers}

The sample farmers who produced fodder faced various problems associated with fodder production. The reported problems were shown in Table 10, that were linked with production and social aspects. Descriptions of these problems are given below:

Table 10. Different problems encountered by the fodder farmers

\begin{tabular}{lcc}
\hline \multicolumn{1}{c}{ Problems } & Producer (\%) & Producer cum seller (\%) \\
\hline A. Production problems & & \\
1. Lack of HYV fodder (low quality seed and fodder) & 73.0 & 78.6 \\
2. Lack of knowledge for fodderproduction & 64.5 & 59.4 \\
3. Lack of available land & 71.5 & 73.8 \\
4. Lack of credit facilities & 67.4 & 60.0 \\
5. Lack of input facilities (i.e. fodder cutting, irrigation, & 62.4 & 67.0 \\
fertilizer, hire labour) & & \\
B. Social problems & & \\
1. Stolen of Fodder & 76.9 & 65.7 \\
2. Altercation with neighbour & 55.0 & 56.0 \\
\hline
\end{tabular}
Source: Field Survey, 2014 


\section{Production Problem}

On the basis of responses received from the sample households, the intensity of problems linked with fodder production among the farmers have been identified. The following are found as main problems by sample households.

\section{Lack of HYV Fodder}

Improved variety of fodder plays a vital role in higher production. Most of the fodder species produced by the farmers were not good quality. Commonly farmers produced local variety fodder or low quality fodder. As a result, the farmers of the study areas mentioned it as one of their major problems in producing.About 73 per cent producer reported this as problem whereas FPS 78.6 per cent.

\section{Lack of knowledge for fodder production}

On an average, 64.5 per cent producer and 59.4 per cent FPS reported that lack of scientific knowledge for fodder production as problem. Besides, they have inadequate knowledge about the utilization of various fertilizer doses economically.

\section{Lack of available land}

Land availability is a vital factor for fodder production. Non availability of land commonly occurs because of converting land into other cereal crops and cultivable lands are far away from the residence of farmer. In the study areas, about 71.5 per cent producer and 73.8 per cent FPS mentioned it as a problem.

\section{Lack of adequate fodder scientist}

Expert or skilled persons are really absent in the field of fodder production in our country.
The fodder scientists provide guideline or valuable advices to the fodder producer properly but it is unfortunate that we don't bave such kind of technical hand. Nearly 53.5 per cent producer and 64 per cent FPS reported it as a problem.

\section{Lack of credit facilities}

The problem of access to credit, it is not only a problem of fodder production but also a problem for crop production. Moreover, fodder is directly linked with livestock production. About 67.4 per cent producer and 60 per cent FPS mentioned lack of credit facilities is a problem.

\section{Lack of input facilities}

Input such as fodder cuttings, fertilizer, labour and irrigations are essential for fodder production. Besides, fodder is labour intensive crop. Timely available of fertilizer or labour at reasonable price was the problem for producing fodder. At peak period when harvesting of paddy is started, huge amount fodder become damage just because of lack of labour. About 62.4 per cent producer and 67 per cent FPS mentioned it as problem.

\section{Social Problem}

Beside the aforesaid problems, farmers in the study areas also faced some other problems such as stolen of fodder, altercation with neighbour etc. Nearly 76.9 per cent producer and 65.7 per cent FPS mentioned that stolen of fodder is a problem. Moreover, sometimes altercation commits with neighbour due to livestock damage some parts of fodder plot. 
Table 11. Probable remedial measures to counter the problems

\begin{tabular}{lcc}
\hline \multicolumn{1}{c}{ Remedial measures } & Producer (\%) & Producer cum seller (\%) \\
\hline $\begin{array}{l}\text { 1. Supply of HYV fodder } \\
\begin{array}{l}\text { 2. Providetraining on fodder production and preservation } \\
\text { through visual and audio visual methods }\end{array}\end{array}$ & 88.0 & 76.0 \\
$\begin{array}{l}\text { 3. Availability of more milk producing cattle breed } \\
\begin{array}{l}\text { 4. Dissemination of scientific production practices of } \\
\text { fodder and postharvest technologies (i.e. silage, hay etc.) }\end{array}\end{array}$ & 76.0 & 82.5 \\
\hline
\end{tabular}

Source: Field Survey, 2014.

Remedial measures to escalate the fodder production

As farmers faced numbers of problems in case of fodder production, processing and marketing, they also have some suggestions to overcome the impediments. The valued suggestions are listed beneath:

\section{Supply of HYV: fodder}

High Yielding Variety (HYV) fodder is a prerequisite for better production. HYV and nutrient enriched fodder is a demand for increasing livestock. About 88 per cent producer and 76 per cent FPS expressed their opinion as a suggestion.

\section{Provide hands on training}

For enhancing technical knowledge and skill, training is a vital tool. More than 85 per cent producer and 82 per cent FPS demanded for providing on different aspects of fodder production and management technology to ensure better harvest in the study areas. Concern authorities along with local livestock officers can play pivotal role in providing short term training to the farmers. In this case, visual and audio-visual methods would be more effective.
Availability of more milk producing cattle breed

Dairy enterprise will be more profitable if prolific or more milk producing cattle breed is available. From the study, it was observed that maximum farmers had local breed dairy cattle.About 76 per cent producer and 65 per cent FPS demanded for availability of more milk producing cattle breed for their dairy farm.

\section{Dissemination of scientific production practices}

In the study areas, farmers are not trained about the scientific production practices of fodder such as silage making and hay making. Many times huge damage occurs due to lack of knowledge for fodder processing. On an average, 78.6 per cent producer and 82 per cent FPS demanded skilled development training for fodder processing.

\section{Conclusion}

No doubt, fodder production is profitable. It created an employment opportunity for the rural people too. Small and medium farmers 
were used more farm land for fodder production as compared with small and large farmers. The study found major proportion of the farmers was in active age group. Agriculture was main occupation of the farmers in the study areas. Fifty per cent farmers had less than five years of experience of fodder cultivation.Cross-bred cattle rearing, milk and meat production increased in the study areas dramatically due to fodder production. Farmers are using more land under fodder production. In Dinajpur district, farmers used more land under fodder production compare to other districts. Cross-bred cattle rearing were higher in Dinajpur also. Farmers cultivated more napier fodder compare with other fodders in the study areas.

Availability of quality fodder is a challenge in the study areas. In this ountry, there is a huge gap between requirement and the availability of fodder for livestock. For increasing the production and minimizing the gap of fodder, recommendations are as follows:

* Quality fodder species should be available to the farmers. Government along with other non-government institutions should come forward and take necessary initiatives to boost up the HYV fodder production system.

Training on scientific fodder cultivation and preservation practices should be provided to the farmers.

\section{References}

BBS. 2012. Bangladesh Bureau of Statistics, Statistics Division, Ministry of Planning, Government of the Peoples' Republic of Bangladesh, Dhaka.

BER. 2013. Bangladesh Economic Review, Ministry of Finance, Government of the Peoples' Republic of Bangladesh, Dhaka.

Dillon J.L. and Hardaker J.B. 1993. Farm Management Research for Small Farmers Development.Food and Agriculture Organization of the United Nations, Rome, Italy.

Faruque, M.G. 2003. Adoption Improved Livestock Production in Practices by Farmers. Progressive Agriculture, Vol. 14 (1\&2): 151-155.

Grover, D. K. And Kumar, S. 2012. Economics of production, processing and marketing of fodder crops in India. http://www.aercpau. com/docs/FODDER_INDIA41

Sayeed M.A., Ataur, Rahman, S.M., Alam, J., Sarker, N. R. and Begum, J. 2008. An Economic study on cultivation of fodder and competing crops in some selected areas of Bangladesh.Annual Report of Annual Research Review Workshop 2008, Pp78-79, Bangladesh Livestock Research Institute, Savar, Dhaka. 